\title{
Highly Ordered of Anatase Titanium Dioxide Nanotube Arrays at Different Calcination Temperatures via Electrochemical Anodization Method
}

\author{
N.E.A. Azhar, M.H. Mamat, A. Shuhaimi, S.S. Shariffudin, and M. Rusop
}

\begin{abstract}
Highly ordered titanium dioxide nanotube arrays (TNTAs) were fabricated via electrochemical anodization of Ti sheet in electrolyte containing aqueous and nonaqueous electrolyte. The formation of highly ordered TNTAs was varied by calcination temperatures $\left(350,450,550^{\circ} \mathrm{C}\right)$ for 120 minutes to investigate the effect of calcination temperature on surface morphology, roughness, crystallinity and band gap energy. The field emission scanning electron microscopy revealed that the prepared TNTAs grow uniformly with average diameter in the range of 48.23 to $52.14 \mathrm{~nm}$ as the temperature increased from 350 to $550^{\circ} \mathrm{C}$. The $\mathrm{X}$-ray diffraction pattern showed the TNTAs exhibit anatase phase with prominent (101) peak recorded for the sample calcined at $450^{\circ} \mathrm{C}$. The transformation from anatase to rutile phase appeared after calcination at $450^{\circ} \mathrm{C}$. The band gap value $(\sim 3.24$ eV) was obtained for all calcination temperature sample due to homogeneity of the TNTAs structures.
\end{abstract}

Index Terms - TNTAs, electrochemical anodization, highly ordered, calcination temperature, structural properties, optical properties

\section{INTRODUCTION}

$\mathrm{N}$ ANOTECHNOLOGY has been introduced in science and technology area such as nano-electronic, material and manufacturing, biotechnology and information technology. In addition, material and structures have excellent properties which enable the nanotechnology to act as main issues in the rapid progress of the science field $[1,2]$. Polycrystal oxide with grain size in nanometer range have received much attention in optoelectronic device. This is because of the relationship observed between optical properties and microstructure [3].

This manuscript is submitted on 26th June 2020 and accepted on 20th October 2020. This work is financially supported by FRGS grant (600IRMI/FRGS 5/3 (081/2017 Institute of Research Management \& Innovation (IRMI), Universiti Teknologi MARA (UiTM) and Ministry of Education Malaysia.

N.E.A. Azhar, M.H. Mamat, S.S. Shariffudin and M. Rusop are from NANO-ElecTronic Centre, Faculty of Electrical Engineering, Universiti Teknologi MARA, 40450 Shah Alam, Selangor, Malaysia (email: najwaezira@yahoo.com, nanouitm@gmail.com).

M. Rusop is also from NANO-SciTech Centre, Institute of Science, Universiti Teknologi MARA, 40450 Shah Alam, Selangor, Malaysia

A. Shuhaimi is from Low Dimensional Materials Research Centre, Department of Physics, Faculty of Science, University of Malaya, 50603 Kuala Lumpur, Malaysia.

1985-5389/C 2021 The Authors. Published by UiTM Press. This is an open access article under the CC BY-NC-ND license (http://creativecommons.org/ licenses/by-nc-nd/4.0/).
Titanium dioxide $\left(\mathrm{TiO}_{2}\right)$ is a semiconductor material for extensive applications due to the ease with which can be utilized to form nanostructure as well as its outstanding optical and electrical properties. Basically, the $\mathrm{TiO}_{2}$ consist of three polymorphs which are anatase, rutile and brookite. From these polymorphs, the rutile phase is the most stable polymorphs while the anatase and brookite are metastable polymorphs. Mostly, the anatase and rutile phases of $\mathrm{TiO}_{2}$ are commonly active applied for electronic devices. The anatase is frequently found in nanostructured $\mathrm{TiO}_{2}$ and being active in oxide process [4]. The $\mathrm{TiO}_{2}$ material is a wide band gap material with anatase $(3.2 \mathrm{eV})$ and rutile $(3.0 \mathrm{eV})$. It has been studied intensively due to its excellent properties such as low cost, good chemical stability and good transparency [5, 6].

Recently, $\mathrm{TiO}_{2}$ nanostructures with the different shape have received attention due to their unique physical and chemical properties such as particles, rods, wires and tubes [3, 7-9]. Amongst these nanostructures, nanotube arrays (NTAs) have received special attention due to high surface-to-volume ratio and high functionality for various application device [10]. Moreover, the anodic TNTAs, each individual tube is perpendicular to the surface which provided a larger surface area, highly uniform morphologies and good module for use in electrical and optical devices [11]. The synthesis of TNTAs has been active research in many area applications such as sensor, dye-sensitized solar cell, photocatalytic and etc [10, 12-14].

In addition, several methods have been developed to growth TNTAs including sol-gel, hydrothermal and electrochemical anodization $[11,15,16]$. Among these method, electrochemical anodization is considered to be ideal method because it is simplicity as well as the reproducibility of the result obtained [17]. Anodization is an electrolytic passivation technique used to increase the thickness of the oxide layer on metal surface. Thus, the ability to grow the TNTAs directly on substrate other than titanium (Ti) sheet not only show the flexibility of anodization process but facilitates the extension of their applications. 
Generally, the $\mathrm{TiO}_{2}$ transforms from amorphous phase to anatase phase and then to rutile phase. All three phases as mention above are depending on the calcination temperature [7]. Mostly, some recent studies have pointed out that the anatase phase is suitable apply for biomedical but in full conversion to anatase is significant used for other application that critically depend on high electron transport efficiency especially in solar cell applications [18]. The electron transport times can be affected by annealing conditions. In fact, there are more challenging to retain the vertical alignment and size of tubular with maintaining a stable anatase phase at certain temperature. Moreover, other researcher reported this devices may facing crucial issue when the higher charge mobility which affected from the charge transport inside and the tubular walls. However, the limitation of TNTAs such as the presence of exciton like trap state can be related to the charge transport rate in TNTAs films compared to particle films [19]. In order to overcome these problems, the trap states and defect of TNTAs can be reduced by applying calcination treatment that not only reduced the grain boundary but also neutralize the oxygen vacancies

The aim of this study is to fabricate the TNTAs films at various calcination temperatures via electrochemical anodization method. The effect of calcination temperature on surface morphology, structural and optical properties of TNTAs films were investigated.

\section{METHODOLOGY}

\section{A. Synthesization of TNTAs films by electrochemical anodization method}

Titanium (Ti) sheet $(0.127 \mathrm{~mm}$, purity: $99.7 \%$; SigmaAldrich) was used as basic substrate to growth the TNTAs structure. The Ti sheet was cleaned inside ultrasonic waterbath for 30 minutes using acetone, methanol and Deionized (DI) water.

The electrolyte solution was prepared by mixing ammonium fluoride, $\mathrm{NH}_{4} \mathrm{~F}(0.3 \mathrm{wt} \%)$, ethylene glycol $(25 \mathrm{ml})$ and DI water (2 v\%) together and stirred for 30 minutes. The Ti sheet and platinum $(\mathrm{Pt})$ sheet were immersed inside electrolyte solution. The Pt sheet was used as cathode electrode and Ti sheet as anode electrode. The anodic film was grown from the Ti sheet by potentiostatic anodization at $35 \mathrm{~V}$. The anodization process was taken for 2 hours at room temperature. Detail mechanism of TNTAs will be explained in Section 3 (a). After anodization process finished, the TNTAs film was calcined at different temperatures $\left(350^{\circ} \mathrm{C}, 450^{\circ} \mathrm{C}\right.$ and $\left.550^{\circ} \mathrm{C}\right)$.

\section{B. Characterizations of TNTAs flims}

Morphology of TNTAs films were characterized by field emission scanning electron microscopy, FESEM (JEOL JSMJ600F). Crystalline and phase composition of TNTAs films were analyzed by X-ray diffraction, XRD (Rigaku (D/MAX2000) and Raman analysis, respectively. Reflectance and optical band gap were obtained via ultraviolet-visible (UV-Vis) spectroscopy in the wavelength ranges between $200-1500 \mathrm{~nm}$ based on diffused reflectance spectroscopy (Varians 5000).

\section{RESULT \& DISCUSSION}

\section{A. Surface Morphology}

FESEM images presented the TNTAs deposited on Ti sheet at different calcination temperatures of $350^{\circ} \mathrm{C}, 450^{\circ} \mathrm{C}$ and $550^{\circ} \mathrm{C}$ as shown in Fig. 1 (a)-(c). The images depicted the top view of synthesized TNTAs at $10 \mathrm{kV}$ and magnification of $50,000 \times$. The mechanism of TNTAs formation on the surface of Ti sheet can be explained below.

The $\mathrm{F}^{-}$is essential factor for the formation of tubular structure. The TNTAs was synthesized using electrolyte that contains fluoride is usually performed under voltage conditions. This electrolyte produced higher growth efficiency and better control of the $\mathrm{TiO}_{2}$ morphology. The formation of NTAs is given below in (1) - (3):

$$
\begin{aligned}
& \mathrm{Ti} \rightarrow \mathrm{Ti}^{4+}+4 \mathrm{e}^{-} \\
& \mathrm{Ti}^{4+}+2 \mathrm{H}_{2} \mathrm{O} \rightarrow \mathrm{TiO}_{2}+4 \mathrm{H}^{+} \\
& \mathrm{TiO}_{2}+6 \mathrm{~F}^{-}+4 \mathrm{H}^{+} \rightarrow\left[\mathrm{TiF}_{6}\right]^{2-}+2 \mathrm{H}_{2} \mathrm{O}
\end{aligned}
$$

The Ti sheet was placed at anode electrode. The applied voltage drives $\mathrm{Ti}^{4+}$ ions from $\mathrm{Ti}$ sheet toward the electrolyte which consists of ammonium fluoride, ethylene glycol and DI water. The oxidation of $\mathrm{Ti}$ into $\mathrm{Ti}^{4+}$ state in (1). $\mathrm{H}^{+}$ions collected during hydrolysis, $\mathrm{F}^{-}$ions migrate to the sites of $\mathrm{H}^{+}$ for electroneutrality and $\mathrm{F}^{-}$ions compete for $\mathrm{O}^{2-}$ sites in the oxide (2). The $\mathrm{Ti}^{4+}$ ions combine with $\mathrm{F}$ - ions to form a soluble titanium hexafluoride complex $\left[\mathrm{TiF}_{6}\right]^{2-}(3)$. The $\mathrm{F}$ - ions migrate towards to the anode. The anions such as $\mathrm{O}^{2-}$ and $\mathrm{OH}-$ originated from the DI water. At the anode electrode. A typical side reaction occurs which generates oxygen and hydrogen bubbles at the platinum $(\mathrm{Pt})$ electrode. Additional ions inside electrolyte will migrate into or away from the anode depending on the electrostatic charge. The $\mathrm{F}^{-}$ions dissolved the oxide and formed porosity in the films and act to maintain the porosity during formation of the nanotubes.

All the calcination sample exhibits highly ordered TNTAs with pore diameter in the range 48.23 to $52.14 \mathrm{~nm}$. It can be seen the NTAs growth uniformly for all samples. There are no changes were observed which all maintained highly-ordered tubular structure. It was remarkable that the NTAs had better ordered structure after calcined and this is attributed to the removal of impurities or residual $\left(\mathrm{F}^{-}\right)$in the channels or on the surface of NTAs during heat process. The thermal stability of TNTAs obtained in $\mathrm{NH}_{4} \mathrm{~F}-\mathrm{H}_{2} \mathrm{SO}_{4}$ electrolyte via anodization $\mathrm{Ti}$ was reported by Xiao et al. [20]. They proposed the NTAs stablilized at temperature lower than $600^{\circ} \mathrm{C}$. These reported values are identical with reported values in this literature. 

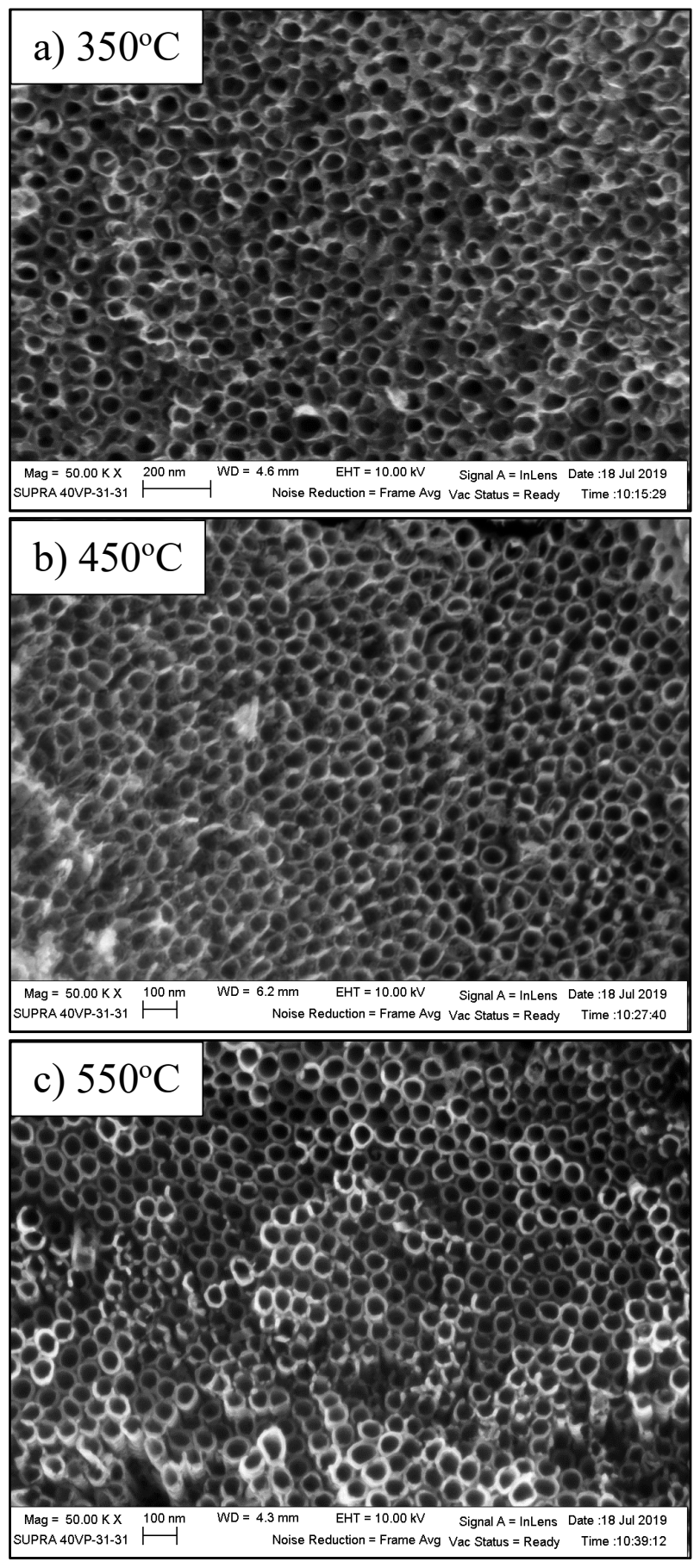

Fig. 1. FESEM images of TNTAs films at calcination temperatures of (a) 350 ${ }^{\circ} \mathrm{C}$, (b) $450{ }^{\circ} \mathrm{C}$, and $550^{\circ} \mathrm{C}$.

Surface topographies images in Fig. 2 showed top view (2D image) and average roughness of synthesized TNTAs was calcined at $450^{\circ} \mathrm{C}$. The top view showed the NTs clearly grown on the metal substrate with dense arrays. The NTAs The 2D image of TNTAs showed similar pattern was obtained through FESEM image (Fig. 1(c)). The average roughness of the synthesized TNTAs were approximately $38.75 \mathrm{~nm}$. The figure shows the regular and uniform nanotubes which leads to an improved organization degree of TNTAs [21]. Hence, the highly porous structure (nanotubes) attributed to the increase of surface area [22]

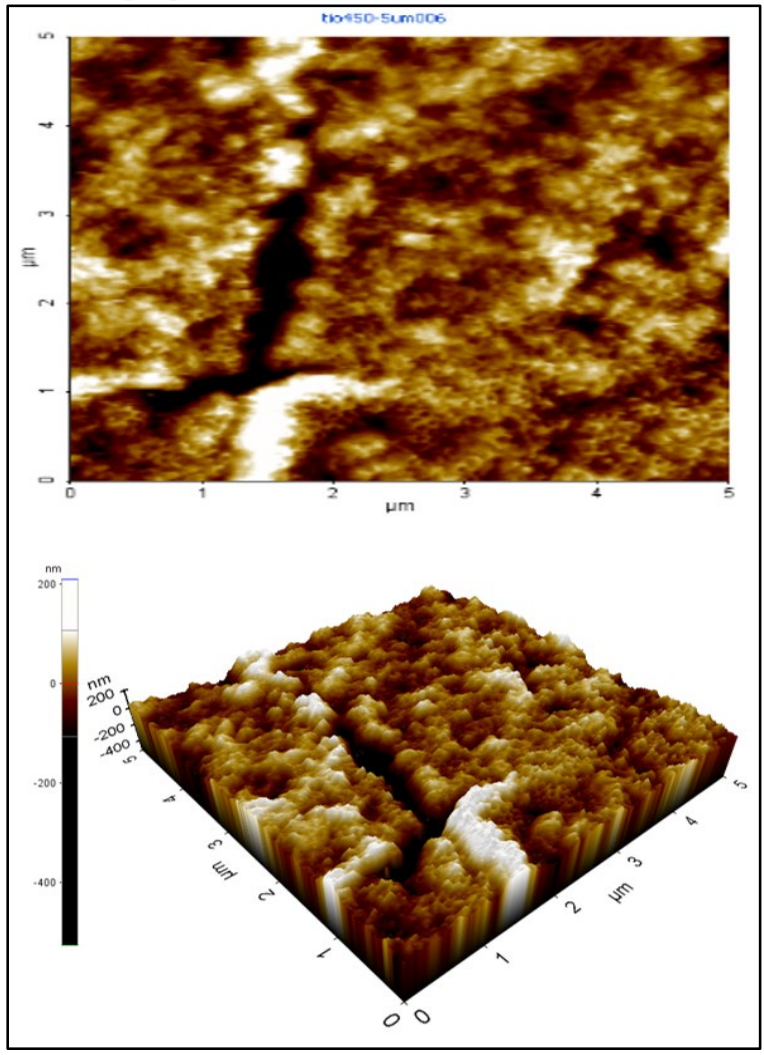

Fig. 2. AFM images of TNTAs films at calcination temperatures of $450^{\circ} \mathrm{C}$.

\section{B. Structural Properties}

Crystalline phase was observed with XRD pattern as shown in Fig. 3. All the peaks were obtained in the range of $20^{\circ}$ to $85^{\circ}$ and have been identified to (101) and (200) plane which corresponding to anatase phase (JCPDS Card No. 00-0040477). Meanwhile the peaks for (002), (101), (102), (110), (103), (112) and (004) planes also observed that correspond to Ti (JCPDS Card No. 00-044-1294). The peaks for (110) and (210) have been detected which correspond to the rutile phase (JCPDS Card No. 00-004-0551).

Based on this result, the (101) diffraction peak at $\sim 25.3^{\circ}$ is referring to the domain peak for the anatase phase. The TNTAs calcined at $350^{\circ} \mathrm{C}$ exhibited rutile phase at (110) and (210) peaks referred to the rutile phase at $44.7^{\circ}$. When the sample calcined at $550^{\circ} \mathrm{C}$, the peak at $27.5^{\circ}$ have been identified corresponding to 110 plane of rutile. The result reported that the transformation phase from anatase to rutile have been occured at low and high calcination temperatures.

The variation of crystallite size TNTAs at different calcination temperatures were calculated from broadening of diffraction peak of (101) plane at $25.3^{\circ}$ using Debye-Scherrer [23]:

$$
\mathrm{D}=\frac{k \lambda}{\beta \cos \theta}
$$

where $k$ is constant $(0.9), \lambda$ is wavelength of the $1.54 \AA$, $\beta$ is the full width at half maximum (FWHM) of the plane in radians and $\theta$ is the Bragg's angle in degrees. Average crystallite size of 
TNTAs have been calculated and listed in Table I. From the table, the sample calcined at $350^{\circ} \mathrm{C}$ and $450^{\circ} \mathrm{C}$ showed the lowest and highest crystallite size of TNTAs, respectively.

In the present study, the anatase phase can be induced at lower temperature of $350^{\circ} \mathrm{C}$ by thermal treatment and the anatase peak shifted to the higher angle which can be related to the method used and particle size. The crystallite size of anatase phase increased as temperature increased to $450^{\circ} \mathrm{C}$ after its nucleation. The crystallite size of TNTAs decreased from 450 to $550^{\circ} \mathrm{C}$ might be due to atoms rearrangement and the phase transformation from anatase to rutile phase occur at higher temperature. Furthermore, the increases of crystallite size with increasing calcined temperature can be attributed to thermally promoted crystallite growth. When the sample calcined at $450^{\circ} \mathrm{C}$, the crystallite size increases with the decreases in the number of surface particles of TNTAs [24]. The crystallite size of anatase starting decreased as temperature increased up to $550^{\circ} \mathrm{C}$ and this indicates that the large anatase grains transform to rutile phase. Moreover, the crystallite size for rutile phase at 110 plane $\left(27.5^{\circ}\right)$ was smaller than anatse phase. This happened because the contribution of the strain on peak broadening that has not been taken into consideration in the calculation. Therefore, the phase transformation is influenced by the temperature of calcination and surface defects of the $\mathrm{TiO}_{2}$ material itself.

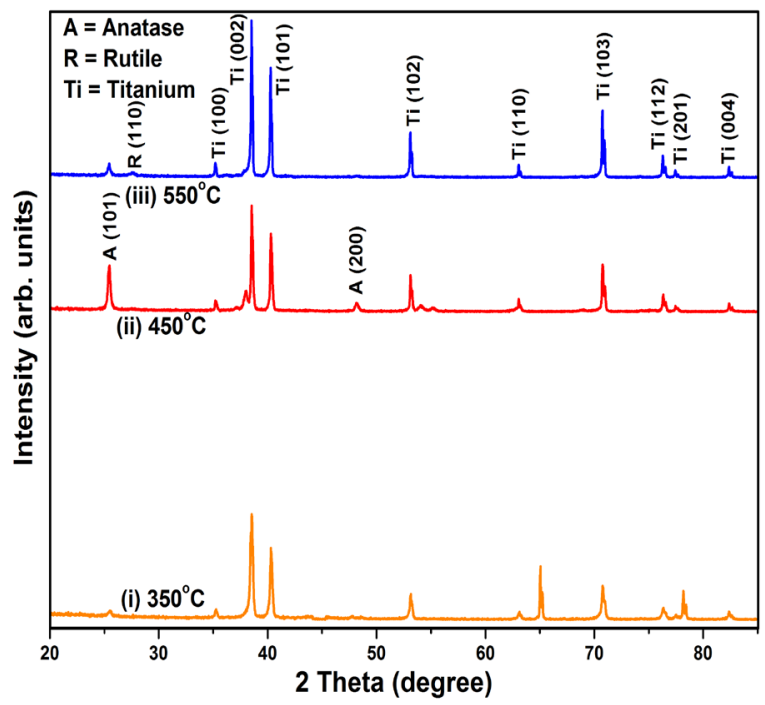

Fig. 3. XRD pattern of TNTAs films at calcination temperatures of (a) $350^{\circ} \mathrm{C}$, (b) $450{ }^{\circ} \mathrm{C}$, and $550{ }^{\circ} \mathrm{C}$.

TABLE I

CRYSTALlite SizES OF TNTAS AT DifFERENT CALCINATION TEMPERATURES

\begin{tabular}{ccc}
\hline \hline \multirow{2}{*}{$\begin{array}{c}\text { Sample } \\
\left({ }^{\circ} \mathbf{C}\right)\end{array}$} & \multicolumn{2}{c}{$\begin{array}{c}\text { Crystallite size, } \boldsymbol{D} \\
(\mathbf{n m})\end{array}$} \\
\cline { 2 - 3 } & $\begin{array}{c}\text { Anatase } \\
\mathbf{2 5 . 3}^{\mathbf{0}}\end{array}$ & $\begin{array}{c}\text { Rutile } \\
\mathbf{2 7 . 5 ^ { \circ }}\end{array}$ \\
\hline 350 & 20.581 & - \\
450 & 29.175 & - \\
550 & 26.218 & 12.864 \\
\hline \hline
\end{tabular}

\section{Optical Properties}

Diffuse reflectance spectra of synthesis TNTAs was obtained at different calcination temperatures are shown in Fig. 4. The TNTAs film calcined at $350^{\circ} \mathrm{C}, 450^{\circ} \mathrm{C}$ and $500^{\circ} \mathrm{C}$ exhibited diffuse reflectance in the range of $3 \%$ to $28 \%, 8 \%$ to $24 \%$ and $3 \%$ to $25 \%$, respectively at wavelength 200 to $800 \mathrm{~nm}$. The average reflectance of $350^{\circ} \mathrm{C}, 450^{\circ} \mathrm{C}$ and $500^{\circ} \mathrm{C}$ is $16.5 \%$, $22.5 \%$ and $15.3 \%$, respectively. The value of ultraviolet (UV) region at $350 \mathrm{~nm}$ for sample calcined at $350^{\circ} \mathrm{C}, 450^{\circ} \mathrm{C}$ and $500^{\circ} \mathrm{C}$ is $8.1 \%, 13.8 \%$ and $9.1 \%$, respectively. The $\mathrm{TiO}_{2}$ layer absorbs the incident light at $\mathrm{UV}$ region. The sample calcined at 550 shows the lowest reflectance and the center wavelength is located at around $550 \mathrm{~nm}$ is very broad among the others due the size of nanotubes was broadly distributed. The incident light could not be absorbed in the $\mathrm{TiO}_{2}$ layer when the wavelength beyond $550 \mathrm{~nm}$.

The band gap energy of the TNTAs was calculated using Kubelka-Munk function formula (5)

$$
\mathrm{F}(\mathrm{R}(\mathrm{hv}))=(1-\mathrm{R}(\mathrm{hv}))^{\wedge} 2 /(2 \mathrm{R}(\mathrm{hv}))
$$

where $\mathrm{F}(\mathrm{R}(\mathrm{hv}))$ is Kubelka-Munk function and $\mathrm{R}$ is the reflectance of TNTAs. The band gap was determined by Tauc's plot by employing the linear correlation between KubelkaMunk function (6)

$$
[F(R) h v]^{1 / 2}=A\left(h v-E_{g}\right)
$$

The band gap value, $\left(\mathrm{E}_{\mathrm{g}}\right)$ of TNTAs films calcined at $350^{\circ} \mathrm{C}$, $450^{\circ} \mathrm{C}$ and $550^{\circ} \mathrm{C}$ are $3.25,3.24$ and $3.25 \mathrm{eV}$, respectively in Fig. 5. The result shows the band gap energy of TNTAs small which attributed to the grain sizes. An increses of grain sizes (densely packed crystalline structure) has weakened the quantum size effect thus lead to the decreased in the band gap energy when calcination temperature increased from 350 to $450^{\circ} \mathrm{C}$ [25]. The grain sizes effect is vice versa when temperature beyond $450^{\circ} \mathrm{C}$. These band gap energy values are approximately equal to each other because of the TNTAs grown highly ordered closely packed structure and more compacted to produced the small grain size due to stronger redox capacity [26]. The redox capacity happened by producing the photo induced charges in TNTAs itself. The grain size (XRD) and morphology of TNTAs can be affected to the optical properties. The band gap energy values depends on the films preparation method and deposition conditions which influenced to the crystalline structure.

TABLE 2

OPTICAL BAND GAP OF TNTAS AT DIFFERENT CALCINATION TEMPERATURES

\begin{tabular}{cc}
\hline $\begin{array}{c}\text { Sample } \\
\left({ }^{\circ} \mathbf{C}\right)\end{array}$ & $\begin{array}{c}\text { Band gap, } \boldsymbol{E}_{\boldsymbol{g}} \\
(\mathbf{e V})\end{array}$ \\
\hline 350 & 3.25 \\
450 & 3.24 \\
550 & 3.25 \\
\hline \hline
\end{tabular}




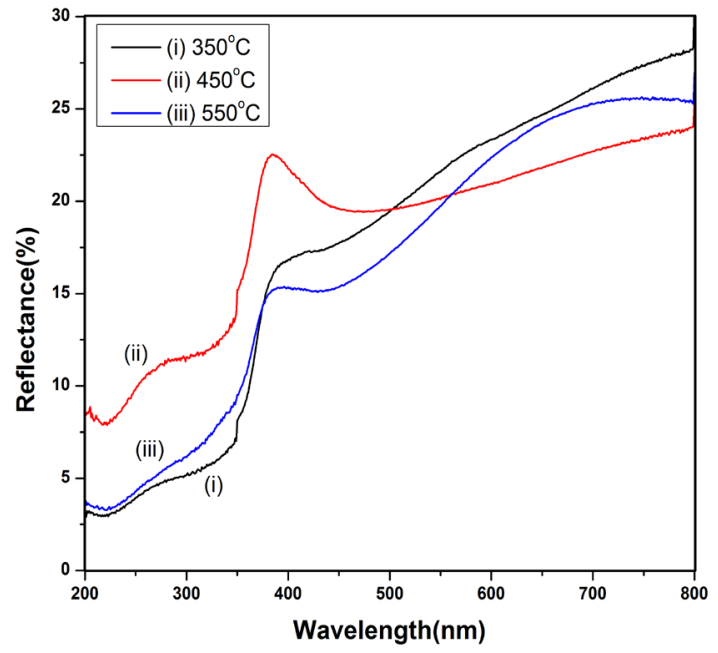

Fig. 4. Reflectance of TNTAs films at calcination temperatures of (a) $350^{\circ} \mathrm{C}$, (b) $450{ }^{\circ} \mathrm{C}$, and $550{ }^{\circ} \mathrm{C}$

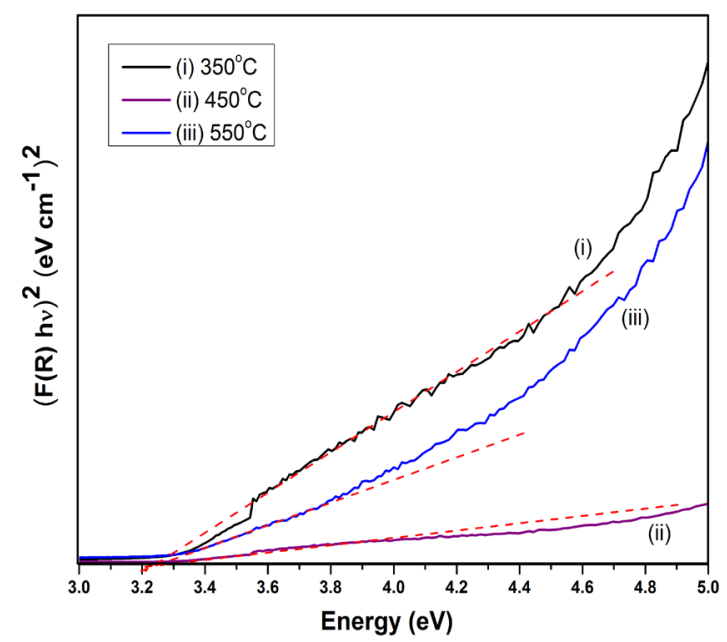

Fig. 5. Optical band gap of TNTAs films at calcination temperatures of (a) $350{ }^{\circ} \mathrm{C}$, (b) $450^{\circ} \mathrm{C}$, and $550^{\circ} \mathrm{C}$

\section{CONCLUSION}

TNTAs films were successfully prepared onto Ti sheet using electrochemical anodization method at various calcination temperatures from 350 to $550^{\circ} \mathrm{C}$. The surface morphology showed that the diameter of synthesized NTAs in the range 48.23 to $52.14 \mathrm{~nm}$ as the calcination temperature increased. The NTAs had better-ordered structure after calcined process. The XRD result showed that the synthesized NTAs have anatase phase for 350 and $450^{\circ} \mathrm{C}$ while anatase-rutile phase at $550^{\circ} \mathrm{C}$. The high crystallite size of anatase phase $(20.59 \mathrm{~nm})$ was obtained when sample calcined at $450^{\circ} \mathrm{C}$. The optical properties showed the band gap energy values of TNTAs is in the range of $3.25 \mathrm{eV}$ when the sample calcined at from 350 to $550^{\circ} \mathrm{C}$. The band gap energy of TNTAs has been dependent on grain size and morphology structure. These results suggested that the properties of synthesized TNTAs films are significantly affected by calcination temperature and promising material for sensing applications.

\section{ACKNOWLEDGMENT}

The authors would like to thank Mr. Salifairus Mohammad Jafar (UiTM Senior Science Officer), Mrs. Ts. Irmaizatussyehdany Buniyamin (UiTM Senior Research Officer), Mr. Muhamad Faizal Abd Halim (UiTM Assistant Research Officer) and Mr. Mohd Azlan Jaafar (UiTM Assistant Engineer) for their kind support to this research.

\section{REFERENCES}

[1] B. Bhushan, "Introduction to Nanotechnology," in Springer Handbook of Nanotechnology, Springer, 2010, pp. 1-15.

[2] J. L. Feather and M. F. Aznar, "Nanotechnologies: Principles, Applications, Implications and Hands-on Activities," in European Commision, 2010, pp. 1-406.

[3] M. A. Rasheed, K. Ahmad, N. Khaliq, Y. Khan, M. A. Rafiq, A. Waheed, A. Shah, A. Mahmood, and G. Ali, "Effect of Electrochemical Reduction on The Structural and Electrical Properties of Anodic $\mathrm{TiO}_{2}$ Nanotubes," Curr. Appl. Phys., vol. 18, pp. 297-303, 2018.

[4] B. Zhang, S. Cao, M. Du, X. Ye, Y. Wang, and J. Ye, “Titanium dioxide $\left(\mathrm{TiO}_{2}\right)$ mesocrystals: Synthesis, growth mechanisms and photocatalytic properties," Catalysts, vol. 9, no. 91, pp. 1-27, 2019.

[5] F. Hanini, A. Bouabellou, Y. Bouachiba, F. Kermiche, A. Taabouche, M. Hemissi, and D. Lakhdari, "Structural , optical and electrical properties of $\mathrm{TiO}_{2}$ thin films synthesized by sol - gel technique," IOSR J. Eng., vol. 3, no. 11, pp. 21-28, 2013.

[6] M. Matsuoka, J. S. Lee, and S. Chen, "Development of Visible LightResponsive Photocatalysts," Int. J. Photoenergy, vol. 2012, pp. 1-4, 2012.

[7] P. Saravanan, M. Ganapathy, A. Charles, S. Tamilselvan, and R. Jeyasekaran, "Electrical properties of green synthesized $\mathrm{TiO}_{2}$ nanoparticles," Adv. Appl. Sci. Res., vol. 7, no. 3, pp. 158-168, 2016.

[8] M. M. Yusoff, M. H. Mamat, A. S. Ismail, M. F. Malek, A. S. Zoolfakar, A. B. Suriani, M. K. Ahmad, N. Nayan, I. B. Shameem Banu, and M. Rusop, "Low-temperature-dependent growth of titanium dioxide nanorod arrays in an improved aqueous chemical growth method for photoelectrochemical ultraviolet sensing," $J$. Mater. Sci. Mater. Electron., pp. 1-16, 2018.

[9] M. A. Othman, N. F. Amat, B. H. Ahmad, and J. Rajan, "Electrical conductivity characteristic of $\mathrm{TiO}_{2}$ nanowires from hydrothermal method," J. Phys. Conf. Ser., vol. 495, no. 1, 2014.

[10] Y. Lim, Z. Zainal, W. Tan, and M. Z. Hussein, "Anodization Parameters Influencing the Growth of Titania Nanotubes and Their Photoelectrochemical Response," Int. J. Photoenergy, vol. 2012, pp. $1-9,2012$.

[11] W. Jun and L. Zhiqun, "Anodic formation of ordered $\mathrm{TiO}_{2}$ nanotube arrays: Effects of electrolyte temperature and anodization potential," J. Phys. Chem. C, vol. 113, no. 10, pp. 4026-4030, 2009.

[12] V. Galstyan, E. Comini, G. Faglia, and G. Sberveglieri, " $\mathrm{TiO}_{2}$ Nanotubes: Recent Advances in Synthesis and Gas Sensing Properties," Sensors, vol. 13, pp. 14813-14838, 2013.

[13] A. Ghicov, S. P. Albu, R. Hahn, D. Kim, T. Stergiopoulos, J. Kunze, C. A. Schiller, P. Falaras, and P. Schmuki, "TiO nanotubes in dyesensitized solar cells: Critical factors for the conversion efficiency," Chem. - An Asian J., vol. 4, pp. 520-525, 2009.

[14] M. Nischk, P. Mazierski, M. Gazda, and A. Zaleska, "Ordered $\mathrm{TiO}_{2}$ nanotubes: The effect of preparation parameters on the photocatalytic activity in air purification process," Appl. Catal. B Environ., vol. 144, pp. 674-685, 2014.

[15] T. Maiyalagan, B. Viswanathan, and U. V Varadaraju, "Fabrication and characterization of uniform $\mathrm{TiO}_{2}$ nanotube arrays by sol - gel template method," Bull. Mater. Sci., vol. 29, no. 7, pp. 705-708, 2006. 
[16] J. Yang, J. Du, X. Li, Y. Liu, C. Jiang, W. Qi, K. Zhang, C. Gong, R. $\mathrm{Li}$, M. Luo, and H. Peng, "Highly hydrophilic $\mathrm{TiO}_{2}$ nanotubes network by alkaline hydrothermal method for photocatalysis degradation of methyl orange," Nanomaterials, vol. 9, no. 4, 2019.

[17] A. L. Escada, R. Z. Nakazato, and A. P. R. A. Claro, "Influence of anodization parameters in the $\mathrm{TiO}_{2}$ nanotubes formation on $\mathrm{Ti}-7.5 \mathrm{Mo}$ alloy surface for biomedical application," Mater. Res., vol. 20, no. 5, pp. 1282-1290, 2017.

[18] S. P. Albu, H. Tsuchiya, S. Fujimoto, and P. Schmuki, " $\mathrm{TiO}_{2}$ nanotubes - Annealing effects on detailed morphology and structure," Eur. J. Inorg. Chem., no. 27, pp. 4351-4356, 2010.

[19] B. Manmadha Rao and S. C. Roy, "Anatase $\mathrm{TiO}_{2}$ nanotube arrays with high temperature stability,” RSC Adv., vol. 4, pp. 38133-38139, 2014.

[20] T. Tian, X. F. Xiao, R. F. Liu, H. De She, and X. F. Hu, "Study on titania nanotube arrays prepared by titanium anodization in $\mathrm{NH}_{4} \mathrm{~F} / \mathrm{H}_{2} \mathrm{SO}_{4}$ solution," J. Mater. Sci., vol. 42, no. 14, pp. 5539-5543, 2007.

[21] N. Pishkar, M. Ghoranneviss, Z. Ghorannevis, and H. Akbari, "Study of the highly ordered $\mathrm{TiO}_{2}$ nanotubes physical properties prepared with two-step anodization," Results Phys., vol. 9, pp. 1246-1249, 2018.

[22] R. Hazan, S. Sreekantan, R. B. S. M. N. Mydin, Y. Abdullah, and I. Mat, "Study of $\mathrm{TiO}_{2}$ nanotubes as an implant application," AIP Conf. Proc., vol. 1704, no. 040009, pp. 1-7, 2016.

[23] B. Choudhury, M. Dey, and A. Choudhury, "Defect generation , d d transition, and band gap reduction in $\mathrm{Cu}$-doped $\mathrm{TiO}_{2}$ nanoparticles," Int. Nano Lett., vol. 3, no. 25, pp. 2-9, 2013.

[24] S. Haq, W. Rehman, M. Waseem, R. Javed, and R. Muhammad, "Effect of heating on the structural and optical properties of - $\mathrm{TiO}_{2}$ nanoparticles : antibacterial activity," Appl. Nanosci., pp. 1-8, 2018.

[25] A. K. M. Muaz, U. Hashim, F. Ibrahim, K. L. Thong, M. S. Mohktar, and W. W. Liu, "Effect of annealing temperatures on the morphology, optical and electrical properties of $\mathrm{TiO}_{2}$ thin films synthesized by the sol-gel method and deposited on $\mathrm{Al} / \mathrm{TiO}_{2} / \mathrm{SiO}_{2} / \mathrm{p}-\mathrm{Si}$," Microsyst. Technol., vol. 22, no. 4, pp. 871-881, 2016.

[26] T. Hoseinzadeh, Z. Ghorannevis, M. Ghoranneviss, A. H. Sari, and M. K. Salem, "Effects of various applied voltages on physical properties of $\mathrm{TiO}_{2}$ nanotubes by anodization method," J. Thoery Appl. Phys., vol. 11, pp. 243-248, 2017. 